\title{
原子力は気候変動・エネルギー問題 同時解決の切り札！
}

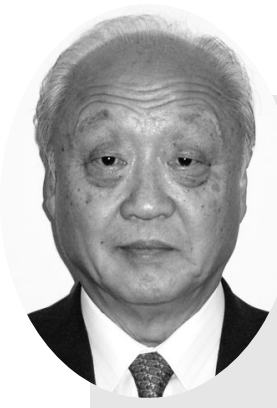

国際海洋法裁判所判事

枊井 俊—(やない・しゅんじ)

東京大学法学部卒業。サンフランシスコ総領 事，外務事務次官，駐米特命全権大使，中央 大学法科大学院教授等を経て, 現職。三菱電 機取締役，外務省顧問等を兼ねる。

今日人類は地球存亡の危機に立っている。 $\mathrm{CO}_{2}$ 等の大量排出で気候が変動し，このままでは取り返しがつか なくなる。北極の水が溶けて白熊の棲家が減り, 南太平洋の島が沈没しかかるなど，海洋環境だけでも大変で ある。その上，中国とインドという10億を超える巨大な人口の国が高度経済成長をするという，史上はじめて の事態が生じ，地球温暖化ガスの排出量はうなぎ昇りになる。石油供給の限界と長期的価格高騰は，無資源国 日本にとって致命的である。

解決策として，水力，太陽光，風力，バイオ燃料等の自然エネルギーの活用が叫ばれ，そのための努力を倍 化すべきことは当然であるが, それだけでは到底不十分で, 根本的な解決にはならない。結論を先に言えば, 温暖化ガスを排出しない原子力の活用以外に現実的な解決策はない。幸いなことに，フランスを除く先進諸国 が長年にわたって原子力をなおざりにしてきた間も，我が国は技術を営々と磨き，国内的な困難にかかわらず 着実に投資してきた。その結果我が国は，長年原子力から遠ざかっていた米国等の先進国との関係においても 技術的な優位に立つことになった。特に，原子力ルネッサンスが国際的な流れになってきた今日，原子力の技 術と経験は，我が国の貴重な資源となった。

このような中で昨年 7 月，洞爺湖 $\mathrm{G} 8$ サミットの首脳宣言が原子力の重要性を認め，その積極的推進を打ち 出したことは画期的である。この首脳宣言は，次のことを明記している。第一に原子力を地球温暖化防止とエ ネルギー安全保障の不可欠の手段とみなす国が増えていること, 第二に核不拡散のための保障措置(セーフガー ド), 原子力安全(セーフティー)及び核セキュリティーの「 $3 \mathrm{~S}\rfloor か ゙$ 原子力平和利用の根本原則であること，第 三に日本の提案により，「3 S 」に立脚した原子力エネルギー基盤整備に関する国際的イニシアチブを開始する こと，第四にこのプロセスにおいて国際原子力機関(IAEA)が役割を果たすこと。この「 $3 \mathrm{~S} 」$ は，日本のブラ ンドである。私が座長を務めた「核不拡散問題検討会」は，昨年 4 月に「原子力平和利用推進と核不拡散強化の ための提言一地球温暖化とエネルギー安全保障の同時解決に向けて一」を政府に提出したが，その中でも， IAEA の検証機能の強化, 原子力供給グループとの連携及び核不拡散抵抗技術の開発,という 3 課題を揭げた。

原子力にとって順風が吹いてきたが，日本の越えるべきハードルは多い。前提条件の「 $3 \mathrm{~S} 」 に$ 関し，特に国 内では，原子炉本体の安全性や災害対策の向上はもとより，周辺施設での事故防止に一層努力すべきである。 些細な事故も反原子力の大合唱を引き起こす。また，原子力の弱点のひとつである放射性廃衰物処理にも一層 真剣に取り組むべきである。これらの問題を解決して原子力に対する国民の信頼を回復し，原子力発電所の新 設を進める必要があるが, 目前の問題として, 現在 $60 \%$ 程度といわれる我が国原子力発電所の低い稼働率を引 上げることが急務である。我が国は，国内でこれらの施策を推進すると同時に，先進国と途上国，特に新興諸 国に，優れた技術と製品を「 $3 \mathrm{~S} 」$ の根本原則の下で供給し，世界の気候変動・エネルギー問題の同時解決に貢 献するとともに，輸出を振興すべきである。温暖化のピンチは，大きなビジネス・チャンスだ。

（2009年 1 月14日 記） 